\title{
Potential and Viability of Rice Husk Based Power Generation in Sri Lanka
}

\author{
Asanka S. Rodrigo and Shantha Perera
}

\begin{abstract}
Due to intense fuel dependency on energy production in the world, cost of energy is now heavily depends on the prices of fossil fuels. Most of the countries in the world are suffering due to this and Sri Lanka is no exception. It is in this context promotion of biomass, as a renewable source, is so vital to the country. Rice being the staple food of the country as well as the crop with highest land area under cultivation, rice husk (RH) generated in paddy processing was found to have a significant potential in power generation. This paper investigates the possibility of using rice husk as a viable source of power generation in Sri Lanka. It is clearly seen that there is a significant potential in the districts of Ampara, Polonnaruwa, Anuradhapura and Kurunegala for power generation using rice husk. It was found that $30 \%$ of excess $\mathrm{RH}$ can be exploited for power generation with an annual energy potential of $180 \mathrm{GWh}$. This potential can be exploited by (1) Commercial scale RH power plants, (2) Small scale power plants under net metering scheme and (3) Off grid RH power plants.
\end{abstract}

Keywords: Rick husk, power generation, viability, gasification, combustion.

\section{Introduction}

Sri Lanka's energy sector has been ailing for the last two decades due to its excessive dependency on petroleum and lack of diversity in energy sources in the energy supply mix. In year 2011, the primary energy share in Sri Lanka was $46 \%$ from biomass, $42 \%$ from petroleum, $12 \%$ from Hydro and rest from the non-conventional renewables $[1,2]$. Initially, almost entire electricity requirement of the country was met by hydropower whilst gradual increase in demand for electricity during the last decade of the $20^{\text {th }}$ century shifting electricity generation more towards thermal power.

There are no proven fossil fuel resources in Sri Lanka. Therefore, there is a high emphasis on introducing non-conventional renewable sources to the electricity sector. Having realized this fact, the government of Sri Lanka set a target of achieving $10 \%$ of electricity demand from non-conventional renewable energy sources by 2015 as set out in the national energy policy of Sri Lanka [3]. It is expected to connect feasible renewables to national grid as distributed generators, which can also be used to optimize the network use [4]. Biomass has been identified as one of the most potential sources of renewable energy for power generation in Sri Lanka [3]. At present, biomass is confined to domestic cooking and to some industrial thermal applications.
In Sri Lanka, rice being the staple food of the country as well as the crop with highest land area under cultivation, produces substantial quantity of rice husk ( $\mathrm{RH})$ as a waste product in paddy processing. Part of $\mathrm{RH}$ produced is used as a source of thermal energy in a few applications while the balance is burnt or dumped in the open air, causing a lot of environmental hazards. If this excess RH can be exploited for power generation that can be used to displace part of oil used in power generation and can add more security to energy supply.

$\mathrm{RH}$ is converted to energy using different technologies such as direct combustion, cofiring, gasification, pyrolysis, and anaerobic digestion [5]. However, the two most proven and common technologies are the direct combustion and the gasification [5, 6, 7]. Most of today's biomass power plants are direct-fired systems where the biomass fuel is burnt in a boiler to produce high-pressure steam, which is used to power a steam turbine driven power generator.

Eng. (Dr.) Asanka S. Rodrigo, Ph.D., M.Sc.(Eng), B.Sc.Eng.(Moratuwa), MIEEE, MIEE, AMIE(Sri Lanka), Senior Lecturer, Department of Electrical Engineering," University of Moratuwa.

Eng. Shantha Perera, M.Sc., B.Sc.Eng.(Moratuwa), CEng, MIE(Sri Lanka), Chief Engineer, Ceylon Electricity Board. 
Gasification is another commonly used option that can be used to generate electricity using RH. This technology is now widely being used in rice growing countries for driving small scale power plants of the order of $10 \mathrm{~kW}-100 \mathrm{~kW}$, though the technology can be used for higher capacities of several Mega Watts $[9,10]$.

Therefore, RH is considered as one of the potential sources of power generation in Sri Lanka as it is renewable, sustainable and indigenous, as the rice is the staple food of the country as well as the crop with highest land area under cultivation. Furthermore, RH is considered as a waste material with negligible commercial value at the moment. Since it being a local fuel, it will provide financial benefits to the local community as well. Therefore, the main objectives of this study were to assess the potential of rice husk based power generation in Sri Lanka and to analyze the economics of harnessing this resource.

\section{Methodology}

First, the paddy production data of the country over last twenty years were collected and analyzed to determine the potential of rice husk production at national level. From the initial investigations, highest $\mathrm{RH}$ generation districts were identified by analyzing paddy production capacity and milling capacity. As a case study, one of the highest potential districts was considered for detailed study. In order to collect data pertaining to availability and distribution of rice mills, their capacities and average rice production, type of rice being processed, a survey was conducted among the rice mills in the selected district. During this survey, data from 650 rice mills were collected and 338 mills were identified as the mills that have significant milling capacity. Using the data, the maximum size of the $\mathrm{RH}$ based power plant and the conversion technology to be used are identified. Finally, a financial analysis for the plant was performed to ensure the viability of the power generation using RH. Even though the case study was confined to a limited area of the country, the results obtained were used to assess the potential at the national level.

\section{Paddy Cultivation in Sri Lanka}

The total land area under paddy cultivation in Sri Lanka is estimated to be about 870,000 hectares [8] at present and this is the highest land area occupied by any single crop accounting for almost $34 \%$ of total agricultural lands in the country [10]. As paddy is a wetland crop that needs a lot of water for its growth, it is cultivated seasonally in Sri Lanka so that it gets enough water from rainy seasons. The two seasons in the year that the paddy is cultivated are known as "Maha" and "Yala" which falls during North-East monsoon (November to February) and South-West monsoon (May to September) respectively. Figure 1 shows the seasonal variation of the paddy production in Sri Lanka.

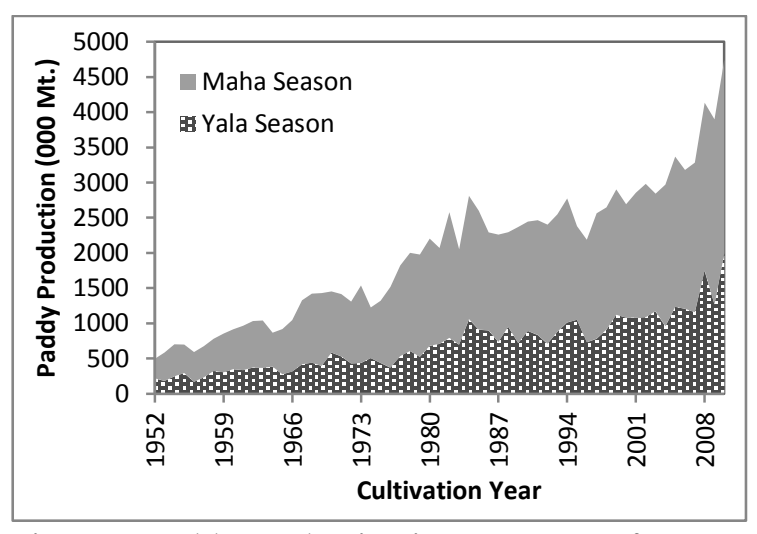

Figure 1- Paddy production in two seasons from 1952 to 2010 (Source: Paddy Statistics, Agriculture and Environment Statistics Division, Department of Census and Statistics-Sri Lanka [10])

Accordingly, it can be seen that production of Maha season is almost double that of Yala season. Since rice is the staple food of the country, demand for rice remains almost constant throughout the year. Therefore, paddy is stored and released to the market as rice at a constant rate. Rice production of the country has increased from about 2.2 million tons to about 4.5 million tons over a period of 20 years. This clearly shows that there is a continuous growth of paddy production in the country. In order to find the paddy production trend in Sri Lanka, paddy production data was fitted into a trend line as shown in Figure 2.

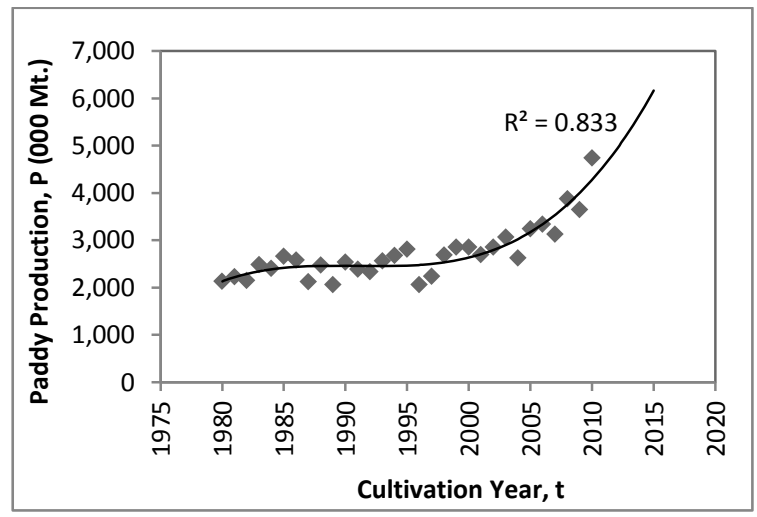

Figure 2- Annual paddy production in thousand tons from 1980 to 2010 
It is clear that there is an increasing trend in paddy production. After liberating the country from 30 year long civil war, most of the paddy lands which had been abandoned in the Northern and the Eastern provinces are now being added to paddy farming and this too will have a considerable impact on the paddy production in the future.

\section{Availability of Rice Husk}

The outer cover of paddy grain is called as the $\mathrm{RH}$ which accounts for about $14 \%-27 \%$ of its weight [11]. The gross energy content of the RH can be determined using Husk to Paddy Ratio (HPR) and calorific value (CV) of RH. CV of RH has been reported by various research works to be in the range of $12.1-15.2 \mathrm{MJ} / \mathrm{kg}[7,12]$. Sri Lanka cultivates different variety of paddy. HPR values for most common paddy verities are given in Table 1 . Since HPR varies between $18 \%$ and $23 \%$ for different varieties of paddy, an average value of $20 \%$ was taken for the future analysis. Similarly, average CV value of 13.6 MJ/kg is considered for the analysis.

\begin{tabular}{lc}
$\begin{array}{c}\text { Table 1- Husk to Paddy Ratio values of } \\
\text { common local paddy varieties }\end{array}$ \\
\hline Paddy Variety & HPR \\
\hline H4 & 0.1972 \\
BG 3-5 & 0.1816 \\
Podiwee A8 & 0.2166 \\
Pachchaperumal & 0.2065 \\
BW 78 & 0.2274 \\
BG 400-1 & 0.2012 \\
LD125 & 0.2300 \\
BG33-2 & 0.1898 \\
BW 170 & 0.2170 \\
MI 329 & 0.2045
\end{tabular}

(Source: National Cleaner Production Centre, Sri Lanka [11])

Even though paddy is cultivated all over the country, paddy is not grown at same scale everywhere. It was found that Ampara, Polonnaruwa, Anuradhapura and Kurunegala districts show a greater potential due to their higher production compared to the rest of the areas in the country (see Figure 3). However, paddy production is not the only indicator that shows the real $\mathrm{RH}$ availability; instead the paddy processing/milling capacity of each district will be a better criterion. Table 2 shows the milling capacity of highest paddy production districts.

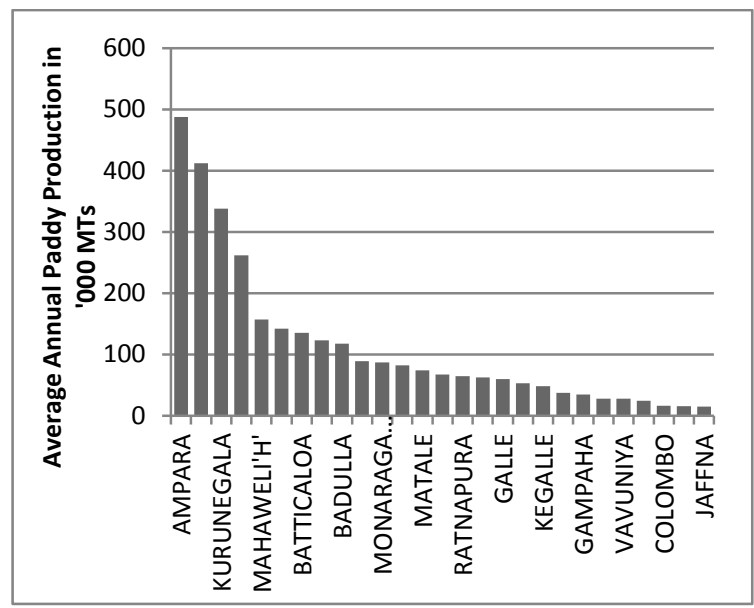

Figure 3- Annual Average Paddy Production in Different Areas (Year 1999 to 2010) (Source: Paddy Statistics, Agriculture and Environment Statistics Division, Department of Census and Statistics-Sri Lanka [10])

Table 2- Milling Capacity of Higest Paddy Production Districts

\begin{tabular}{|c|c|c|c|c|c|c|c|}
\hline & & & & & & & \\
\hline & \multicolumn{7}{|c|}{ No. of Mills } \\
\hline & \multicolumn{5}{|c|}{$\begin{array}{c}\text { Milling Capacity } \\
\text { (kg/Day) }\end{array}$} & \multirow[b]{2}{*}{ 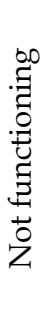 } & \multirow[b]{2}{*}{$\underset{E}{\tilde{0}}$} \\
\hline & $\begin{array}{l}\S \\
\stackrel{8}{v} \\
\text { v }\end{array}$ & $\begin{array}{l}8 \\
\stackrel{2}{ } \\
\text { vi } \\
u \\
\text { v } \\
\text { o } \\
8\end{array}$ & $\begin{array}{l}8 \\
8 \\
10 \\
\text { vi } \\
u \\
\text { v } \\
8 \\
\stackrel{2}{1}\end{array}$ & $\begin{array}{l}8 \\
8 \\
\infty \\
\text { vI } \\
u \\
\text { v } \\
8 \\
8 \\
\text { in }\end{array}$ & $\begin{array}{l}8 \\
\varnothing \\
\stackrel{\infty}{ } \\
\text { v }\end{array}$ & & \\
\hline Ampara & 9 & 4 & 8 & 11 & 55 & 3 & 90 \\
\hline $\begin{array}{l}\text { Polonnaru } \\
\text { wa }\end{array}$ & 28 & 30 & 40 & 19 & 27 & 13 & 157 \\
\hline A'pura & 16 & 18 & 27 & 26 & 20 & 6 & 113 \\
\hline $\begin{array}{l}\text { Hambanto } \\
\text { ta }\end{array}$ & 2 & 2 & 3 & 11 & 28 & 2 & 48 \\
\hline $\begin{array}{l}\text { Kurunegal } \\
\text { a }\end{array}$ & 2 & 10 & 15 & 6 & 4 & 0 & 37 \\
\hline
\end{tabular}

By considering both production and milling data, it was found that Ampara, Polonnaruwa, Anuradhpura and Hambantota were identified as the districts with highest potential. Even though the paddy production is higher in Kurunegala district, milling capacity appears to be comparatively low where the harvest is taken away to another part of the country for milling.

As there were practical limitations in collecting required data island wide, Polonnaruwa was selected for detailed case study, since it is the second highest districts in paddy production as well as a leading area of paddy milling. Ampara, the highest paddy production district, was not selected for the case study due to the lack of data collectors available in the district. 
During the survey, data from 650 rice mills were collected. Out of these mills, data from 338 mills which are considered as mills with significant milling capacity (higher than 2 tons/month) were analysed. Table 3 shows the details of selected mills.

Table 3- Rice mills in Polonnaruwa categorized on capacity.

\begin{tabular}{lrrr}
\hline Scale & $\begin{array}{r}\text { Capacity } \\
\text { (tons/month) }\end{array}$ & $\begin{array}{r}\text { No. of } \\
\text { Mills }\end{array}$ & $\begin{array}{r}\text { Output } \\
(\mathrm{Mt} .)\end{array}$ \\
\hline Small & $\leq 10$ & 191 & 10033 \\
Medium & $>10$ and $\leq 100$ & 94 & 46359 \\
Large & $>100$ & 53 & 243750 \\
\hline Total & & 338 & 300142 \\
\hline
\end{tabular}

Even though, paddy mills are scattered all over the district, it was found that most of the large mills are around Kaduruwela and Minneriya whilst very small portion of mills lying in and around Medirigirya area. RH production in year 2010 was found as shown in Figure 4.

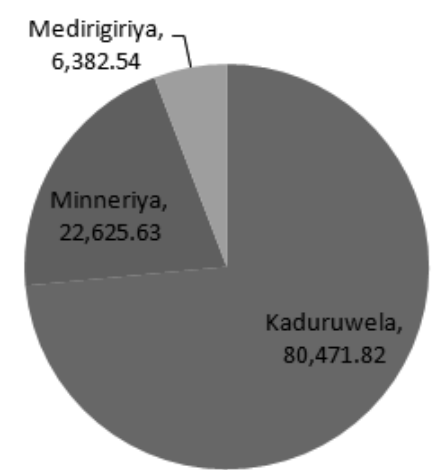

Figure 4- Rice husk production [in $\mathrm{Mt}$ ] in different areas of Polonnaruwa in 2010

$\mathrm{RH}$ in the district was found to be used in different applications. Among those applications, (a) paddy boiling and drying $(55 \%)$, (b) brick kilns $(16 \%)$, (c) poultry farms $(5 \%)$ and (d) sales for other applications like tobacco curing, bakeries and as a fertilizer in agriculture $(2 \%)$ are identified as the key applications and $22 \%$ of excess $\mathrm{RH}$ is left in the district after using $\mathrm{RH}$ for different other applications.

\section{Power Generation Potential in Polonnarauwa District}

$\mathrm{RH}$ is used for most of the activities without any financial transaction. Considering the $\mathrm{RH}$ production of year 2010, minimum potential of the Polonnaruwa district can be calculated as follows;

Total RH production in $\quad-109,480 \mathrm{Mt}$ year 2010

Excess RH left (22\% of total $\quad-24,086 \mathrm{Mt}$ $\mathrm{RH}$ production)
It was assumed that the total RH quantity left can be tapped for power generation, annual electricity generation potential can be calculated by taking $\mathrm{CV}$ as $13.6 \mathrm{MJ} / \mathrm{kg}$ and Conversion efficiency as $15 \%$.

Then the annual electricity generation (Potential) - 13.65 GWh

If about $60 \%$ of this potential can be tapped, the minimum capacity of the power plant that can convert this potential into electricity is about 1 MW at $90 \%$ plant factor.

\subsection{Possible Conversion Technology.}

Even though there are several technologies available for biomass conversion, direct combustion and gasification are the two widely used technologies for $\mathrm{RH}$ conversion. Gasification is widely used for small-scale power plants because of its higher efficiency low cost and simple operation. But this technology is not hassle free due to producer gas produced in gasification contains lots of impurities like tar, ash particles and dust. Gas cleaning is therefore an essential requirement, when using gasification technology for power generation. Therefore, power plants driven by gasification technology require more maintenance.

Compared to gasification, direct combustion is more efficient and easy to apply for cogeneration also. However, this method requires higher investments. Considering difficulties in maintenance and gas cleaning in gasification, direct combustion with steam cycle is selected as the preferred and used for financial analysis of this study.

\section{Financial Analysis.}

Even though there is enough fuel in Polonaruwa to run a power plant of $1 \mathrm{MWe}$, this resource can only be tapped, provided such power plants are commercially viable.

\subsection{Capital cost of the project}

Capital investment of this project includes costs associated with all the plant and equipment, lands, buildings, utility services, project management, design and consultancy, construction and installation works and approvals etc,. Project cost of number of biomass power plants (recently constructed) of the capacity ranging from $1 \mathrm{MW}$ to $10 \mathrm{MW}$ were collected and their capital investment were analyzed. This analysis revealed that capital cost per $\mathrm{kW}$ of most of these power plant falls within the range of 1000 US\$ - 1500 
US\$ [6]. Further, it was found that per kW capital cost of most of the power plants constructed in this region (in Asia using Asian equipment ) were closer to 1000 US\$ while the same for other power plants in Europe and America remained closer to 1500 US\$ margin or above. Therefore the capital cost of this plant was assessed on the basis of 1250 US\$/ kW which is the middle value of the above range. Accordingly, capital cost of this power plant was estimated to be LKR 143.75 million (Exchange rate was taken as 1 US\$ $=115$ LKR).

\subsection{Fuel cost of the power plant}

In Polonnaruwa district, more than $70 \%$ of the $\mathrm{RH}$ produced was found to be used for different applications. From the balance, very small fraction is sold and the remainder is excess. Due to prevailing low demand, this excess $\mathrm{RH}$ has no commercial value and even taking away of this excess RH free of charge from mills is most welcome by millers as disposal is a problem to them. However, if a real demand arises, this situation can change and easily a firm price can be set for RH. Moreover, if $\mathrm{RH}$ is transported there will be an additional cost on top of RH price. As per the information received from the survey, it was found that cost of $\mathrm{RH}$ per $\mathrm{kg}$ at a site ranges from LKR 1.70 to LKR 3.00 depending on the distance of transportation. Considering $\mathrm{RH}$ price plus handling and transportation charges, per $\mathrm{kg}$ cost of RH was assumed to be LKR 3.00 with yearly escalation of $3 \%$ for this analysis.

\subsection{Operation and maintenance $(O \& M)$ cost}

Different literature gives varying values for O\&M cost of biomass power plants. From the records of power plants which are in operation, annual O\&M cost found to be within the range of $3 \%$ to $7 \%$ of capital investment with $5 \%$ yearly escalation [14]. Therefore annual O\&M cost was taken as $5 \%$ of capital cost with $5 \%$ escalation.

6.4 Debt/equity ratio of the capital investment Since Sri Lanka is new to biomass power generation field and success of this kind of projects is not yet proven, 70/30 typical debt equity ratio may not be achieved. Therefore, it was assumed that $60 / 40$ debt-equity ratio is achievable for this kind of power plant.

\subsection{Finance cost and loan repayment period}

It was found that the typical interest rate of project financing schemes of the local banking sector is around $12 \%$ per annum for a period of six years.

\subsection{Tax and incentives}

Income tax of $28 \%$ is levied by the Inland Revenue for local investments and as per the new tax regime of 2012 certain tax concessions are offered to local investors in order to promote private investments within the country [15]. Under this, a period of tax holiday is granted depending on the type and the scale of the investment. The projects with investment between LKR 100-200 million fall into medium scale category where this quantum of investment is eligible for five-year tax holiday. However, renewable power projects are not listed under this category in Sri Lanka. Even though it is not clear, whether the renewable energy investments qualify for a tax holiday, depending on the quantum of investment it was assumed that five-year full tax holiday will be granted for this type of projects, because the country's energy policy is to promote renewable power generations.

\subsection{Returns of the project}

The direct return of this power plant will be the revenue generated from the electricity sale. The expected revenue from the power plant can be estimated using prevailing tariff published by the Public Utility Commission of Sri Lanka (PUCSL) under Standardized Power Purchase Agreements (SPPA) [16]. Under this scheme, a developer can choose one from the two tariff options available. Under option I, three tier tariff is declared while two component out of three in this tariff subject to yearly escalation. Option 2 is a flat tariff with no escalation at all allowable during the first 20 years. For the baseline case analysis, option 2 of the tariff, that is $17.71 \mathrm{LKR} / \mathrm{kWh}$, was considered. Other than that, there can be indirect returns through clean development mechanism (CDM) benefits and ash sale. However, for this analysis these indirect returns have not been considered.

Financial analysis for this conceptual power plant was performed considering different cash flows for a period of 20 years. Table 4 shows the summary of the analysis.

Based on above analysis project IRR and equity IRR was found as $34.2 \%$ and $56.2 \%$ respectively for the baseline case while simple payback period comes to 2 years 8 months. Higher IRR values plus short payback period indicate that implementation of a $1 \mathrm{MW} \mathrm{RH}$ based power plant is financially viable in Polonnaruwa district. 
Table 4- Key Figures of Financial Analysis.

\begin{tabular}{|c|c|}
\hline $\begin{array}{l}\text { Capacity of the Power } \\
\text { Plant }\end{array}$ & $1 \mathrm{MWe}$ \\
\hline Plant factor & $90 \%$ \\
\hline $\begin{array}{l}\text { Expected energy export ( } \\
90 \% \text { of total) }\end{array}$ & $\begin{array}{l}7.0956 \\
\text { GWh/year }\end{array}$ \\
\hline Life span & $20 y r s$ \\
\hline $\begin{array}{l}\text { Capital cost( @1250 } \\
\text { US\$ } \$ \text { kW) }\end{array}$ & $\begin{array}{l}\text { LKR } 143.75 \\
\text { million (@115 } \\
\text { LKR/US\$) }\end{array}$ \\
\hline $\begin{array}{l}\text { Tariff ( Option } 2 \text { of } \\
\text { SPPA) }\end{array}$ & LKR 17.71 \\
\hline $\begin{array}{l}\text { Expected annual } \\
\text { revenue }\end{array}$ & $\begin{array}{l}\text { LKR } 103.10 \\
\text { million }\end{array}$ \\
\hline Debt/Equity ratio & $60 / 40$ \\
\hline Depreciation period & $20 y r s$ \\
\hline $\begin{array}{l}\text { Fuel consumption( @ } 40 \\
\text { tons/day) }\end{array}$ & $\begin{array}{l}13,140 \\
\text { tons/year }\end{array}$ \\
\hline $\begin{array}{l}\text { Fuel Cost( @ } 3.00 \\
\text { LKR/kg) }\end{array}$ & $\begin{array}{l}\text { LKR } 39.42 \\
\text { million }\end{array}$ \\
\hline $\begin{array}{l}\text { Escalation of fuel } \\
\text { cost/year }\end{array}$ & $3 \%$ \\
\hline $\begin{array}{l}\mathrm{O} \& \mathrm{M} \operatorname{cost}(5 \% \text { of } \\
\text { capital) }\end{array}$ & $\begin{array}{l}\text { LKR } 7.19 \\
\text { million }\end{array}$ \\
\hline $\begin{array}{l}\text { Escalation of O\&M } \\
\text { cost/year }\end{array}$ & $5 \%$ \\
\hline Cost of capital & $12 \%$ \\
\hline Loan repayment period & 6 years \\
\hline Tax/ tax holiday & $28 \%$ / 5 years \\
\hline Discount rate & $15 \%$ \\
\hline $\begin{array}{l}\text { Project internal rate of } \\
\text { return (PIRR) }\end{array}$ & $34.2 \%$ \\
\hline $\begin{array}{l}\text { Equity internal rate of } \\
\text { return (EIRR) }\end{array}$ & $56.2 \%$ \\
\hline Simple payback period & $\begin{array}{l}2 \text { years and } 8 \\
\text { months }\end{array}$ \\
\hline
\end{tabular}

However, at implementation stage the values taken can be changed, giving rise to different result. Hence, sensitivity of this project was checked as follows by varying the critical components in the cash flow. The behavior of Pooled Internal Rate of Return (PIRR) and Economic Internal Rate of Return (EIRR) under seven cases, were examined and summarized in Table 5.
Table 5- Summary of sensitivity analysis

\begin{tabular}{|c|l|l|l|}
\hline Case & \multicolumn{1}{|c|}{ Description } & PIRR & EIRR \\
\hline 1 & $\begin{array}{l}\text { If tariff option I is } \\
\text { selected in SPPA a } \\
\text { against option II }\end{array}$ & $32.0 \%$ & $49.4 \%$ \\
\hline 2 & $\begin{array}{l}\text { If capital cost is } \\
\text { based on } 1500 \\
\text { US\$ } / \mathrm{kW} \text { (Capital- } \\
172.5 \mathrm{MRs})\end{array}$ & $26.3 \%$ & $39.1 \%$ \\
\hline 3 & $\begin{array}{l}\text { If the plant factor } \\
\text { drops to 0.8 from } \\
0.9 \text { in the baseline } \\
\text { case }\end{array}$ & $31.5 \%$ & $48.2 \%$ \\
\hline 4 & $\begin{array}{l}\text { If fuel price } \\
\text { escalates 5\% as } \\
\text { against 3\% in the } \\
\text { baseline case }\end{array}$ & $32.2 \%$ & $53.7 \%$ \\
\hline 5 & $\begin{array}{l}\text { If O\&M cost is 7\% } \\
\text { of capital as against } \\
5 \% \text { in the baseline } \\
\text { case }\end{array}$ & $31.6 \%$ & $50.9 \%$ \\
\hline 6 & $\begin{array}{l}\text { If fuel price is } 4 \\
\text { LKR/kg as against } \\
3 \text { LKR/kg in the } \\
\text { baseline case }\end{array}$ & $22.3 \%$ & $32.1 \%$ \\
\hline 7 & $\begin{array}{l}\text { If no tax holiday is } \\
\text { offered as against } 5 \\
\text { yrs in the baseline } \\
\text { case }\end{array}$ & $27.4 \%$ & $39.9 \%$ \\
\hline
\end{tabular}

Results of the sensitivity analysis further shows that even under adverse conditions, the project is financially robust.

\section{Surplus RH availability at country level}

It was recorded that $50 \%$ of the paddy has been found to be milled in commercial scale in bigger mills while the balance is milled by the farmers for themselves in small mills [11]. When these facts are summed up with the annual paddy production, surplus $\mathrm{RH}$ availability of the country was found as $30 \%$ of total $\mathrm{RH}$ production. This is the excess without any use which can be used to generate electricity with an annual energy potential of 180 GWh.

\section{Harnessing RH Power Generation Potential in the Country}

Even though it was estimated that there is a potential of $180 \mathrm{GWh}$ for power generation using $\mathrm{RH}$, harnessing entire above potential may not be viable as a part of this $\mathrm{RH}$ comes from lesser known districts of paddy production in the country. Therefore, setting up of $\mathrm{RH}$ power plants in these districts has to be 
ruled out due to shortage of fuel as well as collection difficulties. Hence, three different models in setting up of $\mathrm{RH}$ power plant were identified that can ensure maximum usage of $\mathrm{RH}$ for power generation. They are (1) Commercial scale $\mathrm{RH}$ power plants, (2) small scale power plants under Net Metering Scheme and (3) Off grid RH power plants.

8.1 Commercial scale RH power plants: Commercial scale grid connected $\mathrm{RH}$ power plants are the most welcome option when considering the current power situation in the country. In order to promote this kind of renewable energy power plants, the PUCSL has formulated an attractive tariff system with LKR 14.53 per $\mathrm{kWh}$ for biomass based power plants [16]. If RH power plants of this scale (order of several MW) are to be set up in the country, it is required to ensure that there are sufficient stocks of $\mathrm{RH}$ to drive such power plants throughout the year. To be more precise, there has to be considerable number of commercial scale paddy mills in the vicinity of a $\mathrm{RH}$ power plant of this scale to keep it running throughout the year. It was found that the Polonnaruwa district shows a potential of $1 \mathrm{MW}$ power plant at viable scale. When looking at the paddy production in the country at district level and the current level of utilization of $\mathrm{RH}$ in the country, possibility of setting up $\mathrm{RH}$ power plants of the scale of several MW (exceeding 2 MW) seem to be far more remote. However, paddy production data of Ampara, Anuradhapura and Kurunegala also show that there is a substantial potential of setting up RH power plant of the capacity ranging from $1 \mathrm{MW}$ to $2 \mathrm{MW}$ in these districts. But, the exact capacity can only be confirmed only after doing a survey on these districts to ensure availability of surplus $\mathrm{RH}$ and the viability of collection of the same.

\subsection{Small scale power plants under Net Metering Scheme}

For commercial scale power generation mentioned above, $\mathrm{RH}$ is more feasible to be collected from commercial rice mills as $\mathrm{RH}$ is available in bulk at such mills with guaranteed supply over a long period. Hence, $\mathrm{RH}$ from other mills (medium and small scale) will be left for being exploited in small-scale power plants in the range of $30 \mathrm{~kW}$ to $40 \mathrm{~kW}$. Results of this study done for Polonnaruwa district, show that the $80 \%$ of total mills in the district are medium and small scale. Even in other areas of paddy cultivation, this proportion may remain same due to limitation of large mills in the country. RH produced in these mills can be used to generate electricity for captive power requirements of these mills while any surplus electricity being exported to the national grid under the Net Metering Scheme introduced by the Ministry of Power and Energy. According to this scheme, any consumer with an electricity supply below the contract demand of $42 \mathrm{kVA}$ is eligible to connect his renewable energy facility to national grid and thereby qualify to pay only for net energy consumption [3]. Therefore, mills which fall into the category less than $42 \mathrm{kVA}$ electricity demand have a very high potential of developing $\mathrm{RH}$ power plant up to the installed capacity of $42 \mathrm{kVA}$ as fuel is available right there and of totally free of charge. Table 6 shows a financial analysis performed on $35 \mathrm{~kW}$ $\mathrm{RH}$ fired power plant operated under Net Metering Scheme by a rice miller.

Table 6- Financial Analysis of $35 \mathrm{~kW}$ plant under Net Metering.

\begin{tabular}{|c|c|}
\hline $\begin{array}{l}\text { Capacity of the Power } \\
\text { Plant }\end{array}$ & $35 \mathrm{kWe}$ \\
\hline Plant factor & 67\% (16 hrs/day) \\
\hline $\begin{array}{l}\text { Expected energy } \\
\text { export ( } 90 \% \text { of total) }\end{array}$ & 184.88 MWh/year \\
\hline Life span & $10 \mathrm{yrs}$ \\
\hline $\begin{array}{l}\text { Capital cost( @1000 } \\
\text { US\$/kW) }\end{array}$ & $\begin{array}{l}\text { LKR } 4.03 \text { million } \\
(@ 115 \text { LKR/US\$) }\end{array}$ \\
\hline $\begin{array}{l}\text { Tariff ( under } \\
\text { Industrial category) }\end{array}$ & $\begin{array}{l}\text { LKR } 12.08 \text { (10.50 } \\
+15 \% \text { fuel } \\
\text { surcharge })\end{array}$ \\
\hline $\begin{array}{l}\text { Expected annual } \\
\text { revenue }\end{array}$ & LKR 2.23 million \\
\hline Debt/Equity ratio & $60 / 40$ \\
\hline Depreciation period & $20 \mathrm{yrs}$ \\
\hline $\begin{array}{l}\text { Fuel consumption( @ } \\
1.11 \text { tons/day) }\end{array}$ & 365 tons/year \\
\hline Fuel Cost & Free \\
\hline $\begin{array}{l}\text { Escalation of fuel } \\
\text { cost/year }\end{array}$ & $5 \%$ \\
\hline $\begin{array}{l}\mathrm{O} \& \mathrm{M} \operatorname{cost}(10 \% \text { of } \\
\text { capital) }\end{array}$ & LKR 0.4 million \\
\hline $\begin{array}{l}\text { Escalation of O\&M } \\
\text { cost/year }\end{array}$ & $5 \%$ \\
\hline Cost of capital & $12 \%$ \\
\hline $\begin{array}{l}\text { Loan repayment } \\
\text { period }\end{array}$ & 6 years \\
\hline Tax/ tax holiday & No tax \\
\hline Discount rate & $15 \%$ \\
\hline $\begin{array}{l}\text { Project internal rate of } \\
\text { return (PIRR) }\end{array}$ & $52.07 \%$ \\
\hline $\begin{array}{l}\text { Equity internal rate of } \\
\text { return (EIRR) }\end{array}$ & $89.69 \%$ \\
\hline Simple payback period & $\begin{array}{l}2 \text { years and } 1 \\
\text { months }\end{array}$ \\
\hline
\end{tabular}


This shows that this option is very attractive to the small and medium scale rice millers. However, most of these rice millers are ordinary people with less technical knowledge. Therefore, it is necessary to promote this option among rice miller by providing necessary technology and financial support.

\subsection{Off grid RH power plants}

At present, the electrification level of the country stands around 90\% [2]. But, still there are some areas in the country with low electrification and most of these areas are remote places. Powering paddy growing areas without grid electricity such as remote villages in Ampara, Anuradhapura and Polonnaruwa by means of small off grid internal combustion engine driven power plants of the capacity of $30 \mathrm{~kW}-40 \mathrm{~kW}$ with $\mathrm{RH}$ gasifiers would be a viable option.

\section{Discussion}

According to the data collected in this study, annual average paddy production of the country was found to be around 4 million metric tons. If assumed that entire paddy production is processed into rice, this much of paddy can produce about 800,000 metric tons of $\mathrm{RH}$ per annum with gross energy content of 10,880 pJ. But, in real terms harnessing this much of energy from $\mathrm{RH}$ is not at all possible due to low efficiencies associated with converting $\mathrm{RH}$ into energy. If it is assumed that conversion ratio of $20 \%$ is achievable, then total net energy potential of RH per annum comes to 1,632 pJ. Tapping this energy again in mass scale becomes challenging as the viability of using $\mathrm{RH}$ for energy production has other constrains such as collection and transportation difficulties as well as supply chain issues.

According to the case study performed on Polonnaruwa district, about $22 \%$ of $\mathrm{RH}$ was found to be left for exploitation in Polonnaruwa district as that portion was surplus after using the balance for above mentioned applications. However, the excess RH level is not uniform all over the country due to variation in use of $\mathrm{RH}$ for different application from area to area. It was found that, about $50 \%-70 \%$ of $\mathrm{RH}$ produced in parboiled rice producing mills goes into paddy parboiling and drying within the same mills. Since paddy parboiling and drying is the number one application of $\mathrm{RH}$, this has become the critical factor in deciding the surplus $\mathrm{RH}$ availability of an area or a district.
It was estimated that about $30 \%$ of excess $\mathrm{RH}$ can be easily exploited for power generation in Sri Lanka with an annual energy potential of 180GWh. It was further revealed that the harnessing this resource for power generation is viable under three different option in Sri Lanka namely (1) Commercial scale RH power plants, (2) Small scale power plants under Net Metering Scheme and (3) Off grid RH power plants. However, it is understood that due to lack of technical knowledge and financial capability, still RH based power generation is at under exploited status.

Therefore, the key players like ministry of power and energy, Sri Lanka Sustainable Energy Authority and Public Utilities Commission of Sri Lanka should take a fresh initiative to shed light on the issues that have hampered harnessing this resource for power generation and find lasting solution to such problems. Among such issues, prominence should be given to following.

Most potential developers of this resource are rice millers themselves. But, their awareness on this kind of power generation is very poor. Hence, an awareness campaign on different aspects of RH power plants has to be launched among the prospective rice millers and other interested parties.

Capital investment must be a critical factor that hampers such projects in the country. If financing is not made to such projects by the lending agencies, that will be a major stumbling block to the implementation of such projects. Therefore, the government should come forward to provide financial assistance to prospective $\mathrm{RH}$ power plant developers through state banks at least till such power plants are popularized in the country.

Tax incentive for renewable power projects are now confined to large scale projects with capital exceeding Rupees 300 million [15]. For prospective developers of $\mathrm{RH}$ power plants, this ceiling would be too high to get eligible for the current tax concession. (Existing potential in the country is not high enough to put up $\mathrm{RH}$ power plants with capital more than Rupees 300 million). Therefore, the government should look at this seriously and need to include tax concession for projects of this magnitude too.

The government should encourage more R\&D works towards rice husk usage for power generation. 
Usage of RH for non-energy application should be discouraged while introducing alternative sources for such applications.

\section{Conclusion}

Based on the analysis presented in this paper the RH based power generation in Sri Lanka is viable with substantial financial return. Most potential developers of this resource are rice millers. But, this resource is not yet exploited due to their lack of awareness on this kind of power generation and lack of financial support. Key players like ministry of power and energy, Sri Lanka Sustainable Energy Authority and Public Utilities Commission of Sri Lanka should take initiative to harness this resource for power generation.

\section{References}

1. Sri Lanka Sustainable Energy Authority, Sri Lanka Energy Balance 2010:An Analysis of Energy Sector Performance.

2. Ceylon Electricity Board, Statistical Digest 2010.

3. Ministry of Power and Energy Government of Sri Lanka, National Energy Policy and Strategies of Sri Lanka, 2010.

4. Rodrigo, A. S., Wijayatunga, P. D. C., "Pricing of Embedded Generation: Incorporation of Exernalities and Avoided Network Losses", Energy Conversion and Management, Vol 48, No. 8, August 2007, pp 2332-2340.

5. Brown, G., Hawkes, A. D., Bauen, A., Leach, M A, "Biomass Applications", Centre for Energy Policy and Technology, Imperial College, London UK.

6. Oliveira, M. O., Neto, J. M., Inocencio, M. C., Ando Junior, O. H., Bretas, Perrone, A. S. O. E., "Viability Study for Use of Rice Husk in Electricity Generation by Biomass", Proceedings of International Conference on Renewable Energies and Power Quality (ICREPQ'12), Santiago de Compostela (Spain), 28th to 30th March,2012.

7. Balat, M., Balat, M., Kırtay, E., Balat, H., "Main Routes for the Thermo-Conversion of Biomass into Fuels and Chemicals: Part 2: Gasification Systems", Energy Conversion and Management, Vol 50, No. 12, December 2009, pp. 3158-3168.

8. Dasappa, S., Paul, P. J., Mukunda, H. S., Rajan, N. K. S., Sridhar, G., Sridhar, H. V., "Biomass Gasification Technology - A Route to Meet Energy Needs", Current Science- Special section:
Application of SET to rural areas, Vol 87, No. 7, October 2004, pp. 908-916.

9. Zhang, L., Xu, C., Champagne, P., "Overview of Recent Advances in Thermo-Chemical Conversion of Biomass", Energy Conversion and Management, Vol 51, No. 5, May 2010, pp. 969982.

10. Department of Agriculture, Sri Lanka, http://www.agridept.gov.lk/index.php/en/cro p-recommendations/808, Visited January 11, 2013.

11. National Cleaner Production Center, Sri Lanka, "Project on Converting Waste Agricultural Biomass to an Energy /Material Resource"; 2010.

12. Agriculture and Environment Statistics Division, Department of Census and Statistics-Sri Lanka, http:/ / www.statistics.gov.lk/agriculture/Padd y\%20Statistics/PaddyStats.htm, Visited November 25, 2012.

13. Kapur, T., Kadpal, T. C. and Garg, H. P., "Electricity Generation from Rice Husk in Indian Rice Mills: Potential and Financial Viability", Biomass and Bioenergy, Vol 10, No. 5-6, 1996, pp. 393-403.

14. El-Kordya, M. N, Badra, M. A, Abeda, K. A, Ibrahimb, M. A, "Economical Evaluation of Electricity Generation Considering Externalities", Renewable Energy, Vol 25, No. 2, February 2002, pp. 317-328.

15. Board of Investment, Investment with Tax Incentives (Section 17) www.investsrilanka.com, Visited January 20, 2013.

16. Public Utilities Commission of Sri Lanka, "NonConventional Renewable Energy Tariff Announcement, Purchase of Electricity to the National Grid under Standardized Power Purchase Agreements (SPPA)", 2012. 